\title{
Experience with Diversity is Not Enough: A Pedagogical Framework for Teacher Candidates that Centers Critical Race Consciousness
}

\author{
Alice Y. Lee ${ }^{* 1}$, Amos J. Lee ${ }^{1}$
}

* Corresponding author

E-mail: alice.lee@ucr.edu

1. University of California - Riverside, Graduate School of Education, Riverside, CA, USA

\section{Article Info}

Received: July 15, 2020

Revised: August 18, 2020

Accepted: September 25, 2020

\subsection{3/icsr.2020.9}

This is an Open Access article distributed under the terms of the CC BY 4.0 International license. (https://creativecommons.org/licenses/by/4.0/)

\section{How to cite}

Lee, A. Y., \& Lee, A. J. (2020). Experience with diversity is not enough: A pedagogical framework for teacher candidates that centers critical race consciousness. Journal of Curriculum Studies Research, 2(2), 40-59. https://doi.org/10.46303/icsr.2020.9

\section{ABSTRACT}

Given the overwhelming whiteness of teacher education, we offer a pedagogical approach rooted in critical race theory, and draw on notions of critical race consciousness to: 1$)$ center a critical race perspective in methods-based coursework; and 2) employ critical race theory to analyze the function and role of clinical fieldwork. In this article, we provide examples of how we engage white teacher candidates to preemptively take stock of their own racial journey and biases prior to being responsible for educating students of color. We also focus on the process of selecting clinical placements and assignments. We explicate how current selection criteria for clinical sites and cooperating teachers are undergirded by systems of white supremacy, and problematize the reality of majority white clinical placements. We further provide suggestions for teacher education programs that pay particular attention to the roles and responsibilities of white teacher educators and predominantly white teacher education programs.

\section{KEYWORDS}

Teacher education, critical race theory, pedagogy, methods courses, clinical sites 


\section{INTRODUCTION}

Teacher preparation programs continue to be overwhelmingly white (Liu \& Ball, 2019). This white majority phenomenon, however, is not recent nor new. For decades, scholars have pointed out the persistence of whiteness within teacher education and its associated problems (e.g., school to prison pipeline, deficit thinking, tracking, school discipline) (Howard, 2019; Ladson-Billings, 1998, 2011; Milner, 2008; Sleeter, 2017; Zeichner, 2006). In light of these critiques and an increasingly non-white student demographic, teacher education programs are scrambling to add coursework and field placements that would better prepare teacher candidates to work with racially diverse students (Liu \& Ball, 2019). Many teacher preparation programs, however, only sprinkle issues of equity into the peripheral by delivering the minimum of one to two diversity course requirements that are intended to inform teacher candidates all they need to know about students and families of color (Sleeter, 2017). Other programs are moving to increase the amount of clinical experience teacher candidates have in diverse spaces, with hopes that prospective educators will be more prepared to work with a diverse student body. In our experiences formerly working at a predominantly white institution with a large teacher preparation school, we have engaged in much discourse about how to incorporate pertinent issues of diversity and equity throughout the sequence of courses and fieldwork. As faculty who have led such endeavors, however, we have found that experience with diversity in these arenas is simply not enough to ameliorate deeply entrenched deficit thinking, particularly from a majority white teacher candidate demographic with backgrounds from predominantly white contexts and communities.

We recognize, therefore, that any substantial discussion about equity in teacher preparation must underscore the urgent need to diversify the teacher workforce. Anti-racist pedagogical frameworks can be beneficial in reducing harm for students of color, but there is no substitute for a racially diverse makeup of teachers in the U.S. (Sleeter, 2017). Thus, we offer a pedagogical framework that anticipates increasing diversity in the teacher preparation pipeline, and, simultaneously, can lay groundwork in programmatic structures that support racially diverse teacher candidates. We do so because we refuse to write for a future that does not imagine a drastically different reality in who becomes prospective teachers. Our twopronged pedagogical approach, then, hinges on: 1) centering a critical race perspective in methods-based coursework; and 2) employing critical race theory to analyze the function and role of clinical fieldwork. For the foreseeable future, an expansive chasm will persist between our anticipation for a more diverse teacher demographic and current teacher education programs monopolized by white teacher candidates. Given this reality, the first prong regarding critical race consciousness work specifically pays attention to how literacy and general methods courses can disrupt white dominant norms and center communities of color. We provide examples of how we engage white teacher candidates to preemptively take stock of their own racial journey and biases prior to being responsible for educating students of color. The second 
prong focuses on the process of selecting clinical placements and assignments. We explicate how current selection criteria for clinical sites and cooperating teachers are undergirded by systems of white supremacy, and problematize the reality of majority white placements.

In this article, we first highlight literature surrounding the pedagogical frame we propose. We divide this literature into two sections: the first focuses on extant notions of critical consciousness, and the work of Whiteness and critical race theory in teacher education. In the second section, we review literature that problematize critical issues in clinical fieldwork, and how such issues play a role in reifying systems of deficit thinking. We then describe what a pedagogical approach that employs a Critical Race Consciousness looks like using examples from each of our own literacy and general methods courses, as well as our experiences leading clinical fieldwork. We integrate suggestions for teacher education programs to pay attention to the roles and responsibilities of white teacher educators and predominantly white teacher education programs.

\section{CRITICAL CONSCIOUSNESS, WHITENESS, AND CRITICAL RACE THEORY IN TEACHER EDUCATION}

\section{Critical Consciousness of Teacher Candidates}

Nieto and McDonough (2011) underscore the role of critical consciousness in developing socially just educators, and synthesize its various forms, including political clarity (Bartolomé, 2004); critical social consciousness (Grant \& Agosto, 2008); and interrogating power, reality, and complex identities (Freire, 1973; Nieto et al., 2008). Critical consciousness is an understanding of the sociopolitical landscape that grants power for some at the expense of others, and affords those with power to live a vastly different reality. Such an awareness is fundamental for prospective teachers interested in engaging in equitable schooling practices. The problem, however, is that most white teacher candidates are not interested in such endeavors. This is evident in the ways white teacher candidates: display white fatigue when learning about race and racism (Flynn, 2015); evade discussions of equity through silence, disassociation, and separation from responsibility (Case \& Hemmings, 2005); resist understanding the structural nature of race and privilege (Crowley \& Smith, 2015); retaliate against faculty of color who teach them about racism and power structures (Evans-Winter \& Hoff, 2011); and actively protect white supremacist ideologies (Picower, 2009). Such whiteness is made possible by "the center of gravity of a program in which the center is defined by White interests" (Sleeter, 2017, p. 158). Thus, teacher education programs sustain teacher candidates' whiteness through various institutional mechanisms, including the racial demographics of faculty, multicultural education coursework that cater to white interests and needs and are separated from the overall program, and the financial role of programs for universities (Sleeter, 2017). 


\section{Whiteness in Teacher Education}

The white center of gravity in teacher education programs directly conflicts with an increasingly non-white educational world. Despite the increase of students of color in public elementary and secondary schools, the majority of teachers in these institutions continue to be overwhelmingly white. In 2017-2018, the percentage of white teachers stood at $79 \%$ while only $48 \%$ of students were white. Teachers of color comprised only $18 \%$ (i.e., $7 \%$ Black, $9 \%$ Latinx, $2 \%$ Asian) of the overall teaching force compared to students of color who comprised $48 \%$ (i.e., $15 \%$ Black, $27 \%$ Latinx, 6\% Asian) of the overall student population (National Center for Education Statistics).The preponderance of white teacher candidates (Sleeter, 2017) in conjunction with the overrepresentation of white teachers already in classrooms provide a long overdue rationale that race should be centered (including in intersectional conversations regarding ability, class, gender, sexuality, etc.) when reforming whiteness in preparation programs. In our experiences, faculty discussions about "cultural diversity" are often refocused to issues regarding ability, class, and gender as a way to obfuscate the central role of race in equity.

\section{Critical Race Theory in Teacher Education}

Centering race and the interrogation of racism and white supremacy are rooted in a critical race perspective. While we employ this perspective to approach the critical consciousness of majority white teacher candidates, Carter (2008) has previously integrated tenets of critical race theory in a pedagogical approach towards Black high school students, termed, "critical race consciousness." Such an approach is a "critical understanding of the asymmetrical power relationships that exist between Blacks and Whites in America," which affords students a deeper understanding of the ways that both race and racism can impact their future opportunities and success (p. 14). Carter (2008) posits that having a framework to interpret historical and structural barriers is vital for Black students to navigate pitfalls endemic within a racial hierarchy, and to empower positive racial identity. Johnson (2018) and Baker-Bell et al. (2017) have also underscored the need to center critical race theory in classrooms. For this article, we draw on Carter's notion of critical race consciousness in our pedagogical approach towards teacher candidates, particularly through our focus of asymmetrical power between white hegemonic schooling norms practiced against Black students. For teacher candidates of color, a critical race consciousness provides a framework to unpack their own racialized experiences, help navigate structural barriers and pitfalls, and offer tools to analyze racist teaching practices. For white teacher candidates, a critical race consciousness opens avenues to deconstruct a white hegemonic system in which they participate in and benefit from, begins the process of decentering white emotions and values (Matias et al., 2014), and provides historical evidence to radically critique a racist schooling system. In previous work (Lee \& Lee, in press) and listed below, we draw on critical race scholars (Bell, 1980; Ladson-Billings \& Tate, 1995) to review key tenets of critical race theory. 
1. Race and racism are central and interconnected to every aspect of U.S. society. CRT rejects the notion of a post-racial or colorblind society. CRT posits that race and racism are endemic within everyday life, has a permanency within U.S. society/institutions, and is so commonplace that only the most egregious forms of racism are acknowledged, thus de-emphasizing all other forms of racism present in daily life.

2. One's whiteness is a property right. CRT also argues that U.S. society is based on property rights and that a person's whiteness is considered as their property. Under a system of white supremacy, whiteness has value and racism is used to maintain a racial hierarchy in which white people dominate.

3. Societal changes must converge to white interests. This notion posits that any progress made for people of color, particularly Black and Brown communities, is achieved only when it "converges with the interests of whites" (Bell, 1980, p. 523). And, since racism is permanent, the progress established can be reversed based on whether or not it continues to benefit white people.

4. Majoritarian views are rooted in false notions of meritocracy, neutrality, and ahistoricism. Majoritarian views are narratives that substantiate ideologies rooted in ahistorical notions (e.g., slavery ended a long time ago and no longer affects us today). Ahistoricism rejects historical contexts (e.g., legal, social, political) and distorts our understandings of current forms of subordination. These notions often lead to myths of a meritocratic society, in which everyone has the same opportunities and chances to succeed, and false beliefs that the law is neutral, objective, and fair to people, regardless of race. While people of any racial background may hold these views and ideologies, they mostly serve the interests of white people, and thus, support white supremacy.

5. The experiential knowledge of people of color need to be centered as sources of knowledge. CRT purposefully centers the experiences, stories, and narratives of people of color as meaningful and instructive. People of color's voices are valuable and necessary, particularly to destabilize white hegemony.

6. Racial issues are inherently intersectional and interdisciplinary. While CRT promotes the centrality of race within analyses, it also acknowledges that race intersects with all other forms of subordination (e.g., classism, sexism, ableism, etc.), and thus, must be interdisciplinary and intersectional in its interpretation and study of racial inequality (e.g., DisCrit, LatCrit, QueerCrit, TribCrit, etc.).

7. Justice and liberation must include a commitment to praxis. Critical race theory praxis moves CRT beyond intellectual endeavors, and underscores the need for a movement that directly impacts and benefits communities of color as theory meets practice.

In order to broaden students' critical race consciousness, we employ these critical race tenets within teacher education. These tenets provide the necessary explanatory framework to center race and racism in the analysis and critique of school systems, including teacher preparation at the collegiate level. Decentering whiteness as normative is essential within 
teacher education programs (Ladson-Billings, 1998). Not interrogating how whiteness is embedded within teacher preparation continues to disadvantage and harm students of color, particularly Black, Brown and Indigenous students who do not benefit from white mainstream norms. Ladson-Billings $(1998,2011)$ contends that in order to build an equitable and socially just future for people of color, we must dismantle white dominance within schools and colleges, deconstruct oppressive school-related structures, and reconstruct agency for students and teachers of color.

Though programs may have verbal commitments to dismantle white supremacy or antiracism, such commitments are empty without systemic change. Milner (2008) points to interest convergence as a governing tenet to explain why there has been minimal progress for Black communities, and is only achieved when aligned with white interests (Bell, 1980). This is evident in "progress" made towards equity in teacher education programs when changes are made to equally benefit white educational interests. For example, implementing equity-based curricula intended to bring issues of racism to the forefront can be beneficial to people of color but are often focused primarily on white teacher candidates' experiences and in trying to create a safe space for them to talk about race (Milner, 2008). Also, providing diverse clinical placements changes the overwhelming whiteness of classroom experiences, but at the same time increases the employability of white teacher candidates in a demographically changing landscape (Ladson-Billings, 2011). Finally, while hiring faculty of color provides additional opportunities to enter academia, these hiring decisions also benefit the reputation of predominantly white teacher education programs (by appearing to be less racist) and often come at the mental expense of faculty of color (Evans-Winter \& Hoff, 2011).

White interest convergence also governs program-related issues, particularly when white teacher candidates are provided an option of whether or not they want to deeply pursue issues of equity (Sleeter, 2017). Creating a diversity cohort or a specified curricula track for those who are interested in learning more about issues of equity gives white teacher candidates a choice that caters to their fatigue and fragility. Such tracks often exist under the guise of matching teacher candidates to where they envision as their future teaching placements. Undergirding these options, however, are the assumptions that white suburban and rural schools do not need teachers with deep knowledge about inequities and that students in these schools are somehow exempt from an anti-racist education. Offering white teacher candidates a programmatic choice to deeply pursue issues of equity conveys the message that dismantling white supremacy and fighting for a more just world is an optional activity. Those who do not choose a diversity cohort are often limited to a required course related to equity, in attempts to spare white teacher candidates from thinking and conversing about race outside their comfort zone, a privilege not granted to teacher candidates of color. Moreover, when teacher candidates and teacher educators are both white, there can be a shared interest (e.g., white fragility, white fatigue) to minimize the amount of time spent in deconstructing racism within their own practices (Milner, 2008; Sensoy \& DiAngelo, 2011). Therefore, teacher education 
programs that promote their one or two mandated equity-related courses, offer optional curricular tracks focused on equity, and/or hire some faculty of color as a sign of change, substantiate watered down notions of social justice that do little to improve teacher preparation for a more racially just future (Ladson-Billings, 2011; Zeichner, 2006).

\section{PROBLEMATIZING CLINICAL FIELDWORK IN TEACHER EDUCATION}

\section{Is Clinical Fieldwork More Relevant Than Coursework?}

Part and parcel of teacher preparation is clinical fieldwork, which has the potential to offer teacher candidates valuable learning experiences and apprenticeship in the classroom. However, while teacher candidates largely believe that their clinical experiences are the most valuable part of their programs (Hollins, 2011), they are often riddled with issues. Entering a classroom space without having a critical framework/race consciousness to understand the socio-political environment that schools are situated in continues to propagate majoritarian views and often reproduces deficit mindsets that harm children of color. As Ladson-Billings (2011) notes, teacher candidates regularly critique foundational courses that deal with history, philosophy, or psychology to be non-related or too far removed from being relevant in the classroom space. However, foundational courses are profoundly relevant as they afford teacher candidates the opportunities to develop an explanatory framework and critical lens to identify and ameliorate structures of inequity embedded within schools.

\section{A Critical Eye on Field Placements}

Ladson-Billings (2011) and Nieto and McDonough (2011) provide a warning for teacher education programs in regards to their pursuit of locating enough field sites. The goal of finding enough placements for their teacher candidates places too much emphasis on the willingness of school districts to accept teacher candidates, instead of a critical review of the district's stance and actions on issues of equity. Simply trying to find enough placements puts teacher education departments solely into the hands of school districts, administrators, and teachers who have varied interests in hosting teacher candidates. In addition, accepting new clinical placements without critically reviewing classroom spaces and cooperating teachers can reinforce deficit views within teacher candidates (Nieto \& McDonough, 2011). The practice of placing white teacher candidates in the hands of white cooperating teachers without first interviewing and getting to know their beliefs and practices regarding students of color must be re-examined (Ladson-Billings, 2011).

Moreover, the disadvantages of having teacher candidates' "view of education" come from "the sole purview of whites" must be factored in when deciding on clinical placements ( $p$. 366). "The prevailing discourses of the field experience" (p. 369) must be critiqued, particularly those surrounding the "culture of poverty," which must be dismantled. As Bomer et al. (2008) and Sato and Lensmire (2009) assert, blaming families, communities, and students for their 
perceived failings continue discourses that reinforce a deficit frame of non-white students. Cooperating teachers who blame families of color for what they perceive to be "underperformance" reify meritocratic myths and white supremacist ideologies--these views should function as a warning sign for teacher education departments. Furthermore, Cornbleth (2008), Zeichner and Tabachnick (1981), and Nieto and McDonough (2011) contend that teacher candidates do not sustain new knowledge about equity and diversity acquired via coursework when entering schools that center white hegemonic discourses. Much is at stake when deciding clinical placements and participating cooperating teachers. Later in this article we outline a selection criteria for how to better choose fieldwork sites.

\section{A PEDAGOGICAL FRAMEWORK TOWARD FOSTERING CRITICAL RACE CONSCIOUSNESS IN TEACHER EDUCATION PROGRAMS}

We offer a framework of racial and economic justice that challenges the performative ways teacher education programs purport to support diversity. Designating a portion of a methods course as "diversity-related" or "urban-education" focused does little to address the complexities of race and racism within public schools. Re-designing one section of a standard multi-section course as urban is also performative because it seeks the least amount of disruption to the status quo, and stereotypes equity issues as being solely relevant to urban areas--which is a false and dangerous notion. Given our current sociopolitical context, it is clear that students from suburban to rural schools are in dire need of an anti-racist curricula in order to foster a more informed citizenry. Further, faculty of color are often asked to critically modify coursework, which involves overseeing white instructional or clinical adjunct faculty who are resistant to implementing such changes. White supremacist practices can also be reinforced when resistance among white adjunct faculty is validated and tenure-track faculty of color are asked to provide a rationale for making critical changes. Anti-racist praxis can no longer be isolated to one required course, optional "diversity" programmatic choices, nor superficial integrations of portions of coursework--which almost always fall back on faculty of color who are provided no support from the inevitable fallout of whiteness. We argue, therefore, for a multi-pronged pedagogical approach in methods-related coursework, whereby future teachers grow in their understanding of how critical racial awareness is necessary, and, without it, racist practices will be reproduced in their future classrooms and schools.

\section{Critical Race Consciousness in Methods-Based Coursework}

\section{Literacy Methods (Alice)}

In my experiences teaching both introductory and advanced literacy methods courses, I foster a critical race consciousness by centering issues of race that challenge white supremacist ideologies and literacy practices throughout the semester. While I draw on all the CRT tenets through various learning engagements, for the purposes of this paper, I focus on the ways I 
utilize tenets four, five, and six to replace white monolingual norms with Black Language. While I incorporate other languages, such as Spanish, Mandarin, etc., into discussions, I employ Black Language as a lens by which to consider myriad literacy topics because of the ways Black Language speakers continue to be unrecognized as linguistically legitimate, and for the interchangeable ways they are discriminated against by race and language.

Tenet four focuses on challenging majoritarian views, particularly ones often perceived as neutral. One majoritarian view that dominates language and literacy practices in schools is the notion of "standard" English--the assumption of its linguistic legitimacy, and the belief that it should be a linguistic norm for all students. I begin the semester challenging this majoritarian view of "standard" English by pointing out how its existence and assumptions about it are ahistorical, since the only standard thing about it is the way in which it became perceived as standard--namely by white people in power across time and space (Lippi-Green, 2012). Thus, the broad acceptance and enforcement of "standard" English as neutral (and oftentimes academically positive and necessary) reinforces white linguistic norms and sustains white supremacist norms in schooling. Pushing against "standard" English becomes a recurring theme in my class when considering a variety of literacy topics, such as reading assessments, building classroom libraries, and selecting instructional texts.

The term "standard" English also elicits discussions about raciolinguistics, and how language and race function as a proxy for one another (Smitherman, 2017; Alim, Rickford, Ball, 2016). These discussions are inherently rooted in the sixth tenet of CRT, which underscores how race intersects with all other forms of subordination (e.g., classism, sexism, ableism, etc.) (Crenshaw, 1989), and thus, can be more broadly understood in conjunction with other disciplines. As mentioned above, the historical construction of "standard" English is intertwined with white linguistic norms. Consequently, I draw on Baker-Bell's (2018) use of the terms, "White Mainstream English" (WME) and "Black Language" to signify how race and language are deeply intermeshed. I also explain that not all Black Language speakers are Black (Paris, 2011), and that not all Black people speak Black Language. However, given the Afro-centered historical roots of the language, and how pervasive discrimination against Black Language is a form of anti-blackness, the term, "Black Language" refers to both the racial and linguistic racism incurred by Black speakers of the language (Baker-Bell, 2020).

I draw on the fifth tenet of CRT, centering the experiential knowledge of people of color, to replace white linguistic norms with the linguistic repertoires of Black Language. For example, in teaching basic linguistic concepts (i.e., phonetics, semantics, morphemes, syntax), rather than normalizing WME structures, I showcase how each of these concepts appears in Black Language. In doing so, teacher candidates are not only exposed to the various linguistic concepts, but also learn that Black Language is linguistically legitimate and not "slang" or "incorrect English," as many often assume. In approaches to reading and writing instruction, I challenge students to broaden their understanding of literacy beyond a written text, and to consider how community practices shape our linguistic repertoires. Black Language speakers, for example, often share 
contexts in which oratory performance is valued, with discourse patterns (e.g., call and response, employing directives versus questions) that differ from many white families (Smitherman, 1977). Such discussions illuminate for teacher candidates how the instruction of key literacy concepts must take into account the rich social and cultural practices of students, particularly when those norms are different from that of the teacher. I intentionally integrate Black Language as a recurring concept in teaching literacy concepts throughout the semester, since my research and extant literature underscore how critical consciousness cannot be fostered in one or two lectures.

Currently in the state of Illinois, a primary way to measure and identify students' literacy identities is through a one-minute reading fluency test in which teachers grade these tests based on how many words are orally read "correctly" and "incorrectly." The grades, however, are subjectively based on teacher judgment, and their (lack of) knowledge about Black Language. I disrupt these practices for teacher candidates through an in-class activity in which they conduct one-minute fluency tests on each other through an excerpt of Young's (2010) "Should Writers Use They Own English," which is written in Black Language. After teacher candidates are graded on how correct their oral reading was (based on Black Language pronunciation), I ask them how reading in Black Language affected the speed and comprehension of their reading. Most share that they lack confidence reading aloud in Black Language, and thus, their oral reading is slower, and they need to re-read phrases in order to comprehend. I then ask teacher candidates to imagine if Black Language was the main mode of communication in every textbook, every book in classroom libraries, all instruction, and every interaction with teachers and principal-how would they feel about reading, about school, and about learning? At this juncture, many teacher candidates reach an epiphany about the harm done to Black Language speaking students, and we use this learning engagement as a starting point for creating critical instructional units and selecting children's literature focused on social justice.

\section{Social Studies Methods (Amos)}

In my experience teaching social studies methods for early childhood/elementary settings, I utilize two main pedagogical approaches in order to foster teacher candidates' critical race consciousness. The first pedagogical approach uses race-centered critical self-reflections as a way to draw out teacher candidates' understanding about how racial privilege works within society. The second approach uses online atlas maps, case studies, and state report cards to illustrate the interconnectedness of housing segregation, family income, and schooling opportunities to emphasize the systemic nature of racism. The goal of these approaches is to foster teacher candidates' critical race consciousness. Being a teacher educator of color in a predominantly white teacher education program, I often find myself as either the only person of color or one of very few, in a white majority classroom. My lived experiences differ vastly from my white teacher candidates' lived experiences. Additionally, trying to develop my white teacher candidates' critical race consciousness based on their limited experiences with racism 
is challenging. To address these challenges, race-based critical self reflections are necessary to begin the journey of fostering a deeper understanding regarding how race functions in and governs everyday life.

\section{Race-Based Critical Self Reflections}

For many of the white teacher candidates in my classes, going to college is their first consequential experience with racially diverse people. Their hometowns, either rural or suburban, along with their social spheres consist of very few people of color. Given that most of them have not experienced racism on a daily basis, racial discrimination is often seen as isolated incidents enacted by a small racist minority. They do not see how race plays a lead role in systems such as education, particularly as it relates to curriculum, pedagogy, and classroom management. Thus, in order to foster teacher candidates' critical race consciousness, I have them complete a critical self-reflection outlined by Milner et al. (2018) in These Kids Are Out of Control: Why We Must Reimagine "Classroom Management" for Equity. This critical reflective autobiography begins the metacognitive process by asking a range of questions to foster teacher candidates' understanding of how race affords privileges previously gone unacknowledged. The following are a few of the excerpted questions (see Appendix for full list of questions):

- What is your racial background? How do you know?

- In what ways does your racial background privilege you (or not) in society?

- How and when did you first see yourself as a racial being? How do you know?

- In what ways do your race and socioeconomic background shape your worldview, what you do, how you experience the world, and what/how you teach?

- How does your racial and socio-economic background influence decisions you make about what you emphasize in course content, how to teach it, and classroom management practices?

- How does your personal experience with regard to family structure and family life patterns growing up shape your expectations of student behavior in class?

From my experiences as a teacher educator, while these autobiographical questions may seem straightforward, they are not interpreted, understood, or valued in the same way by all the teacher candidates. Therefore, I begin by having my teacher candidates think through, with one another and later as a whole class, how these questions are directly related to their classroom practices. This initial dialogue is important because resistance to answering questions regarding racial privilege has been a continued norm in my white majority classes. I also intentionally give them class time to complete this assignment so that I can check-in with students and provide feedback as they go. I make it a habit to check-in with everyone and if their final responses to the above questions are brief or superficial, I know that we have to talk more about the nature of the assignment. Once they have all completed the assignment, I organize students in groups of three and have them read their responses to one another with 
one specific direction: They must read their written responses aloud to each other rather than summarizing what they wrote. For many of my teacher candidates, white fragility and white fatigue prevents them from thinking about racism on a daily basis as most people of color are required to do. The act of summarizing can be used as a tool to avoid and minimize time spent talking about an uncomfortable subject. Understanding, however, that students are continuing to learn and grow in their knowledge of racism, I create pedagogical room for them to grow by allowing re-writes of this assignment. My hope is that if they initially struggled to answer the questions, being a part of a dialogic conversation with their peers gives them the opportunity to think further about the centrality of race within education. My goal is to help teacher candidates understand that there is no neutrality within the classroom, and we cannot assume or give the benefit of the doubt that teachers will be fair and unbiased arbiters for children of color.

After they read and discuss each others' reflections and thoughts in small groups, I ask them to highlight common themes from their collective reflections. Oftentimes themes highlight how little experience with diversity many white teacher candidates have had. For example, students share about how they did not have non-white friends until entering college or about how they are not sure how race plays a major role in the classroom and in schools. Other themes center on their plans to never discriminate based on a student's race in their future classrooms, to treat all students the same, and to not base their classroom management decisions on a child's race. While on the surface this sounds wonderful, CRT informs us that racism is ever adapting to its environment. Color-blind notions harm children of color as race and racism govern daily life, a central CRT tenet. Within teacher education, if teacher candidates believe that all they need to do is not discriminate based on a person's race, then they believe the solution lies outside of themselves. It is a problem for those who discriminate based on phenotype only. But as Kohli (2009) notes, "even though racism is tied to race, it is not always acted out based on racial categories; it can also manifest as discrimination based on factors affiliated with race or ethnicity such as language, religion and culture" (p. 237). Discrimination based on wearing a hijab, based on speaking Black Language or Spanish with friends in a classroom space, or based on a student having a parent who is incarcerated are all affiliated factors of race that must be recognized. It is not as simple as stating, "I will not discriminate based on a student's race." While well-meaning, this refusal to see the ways in which whiteness discriminates in education continues to disadvantage non-white students.

Atlas Maps, Podcasts as Case Studies, and Funding Data

CRT does not view race as only a physical trait or as a person's phenotype; instead, race has power, privilege, and benefits within the U.S. More specifically, the tenet of whiteness as property is a framework that explains the way a person's race is a form of property that grants real and tangible rights (e.g., political, social, financial). In order to understand structural privileges afforded by a person's race, teacher candidates are presented with and think through 
multiple sources of evidence related to racial privilege and racial discrimination within education. The first source consists of various atlas maps that present social mobility data through "The Opportunity Atlas" (Chetty et al., 2018), which show household income based on geography. Specific zip codes or cities can be inputted and the household income discrepancy based on where a person lives is displayed. What is evident in these maps is that household income is not neatly spread out within a geographical location. Specific neighborhoods have much lower income than others. I then show "The Racial Dot Map" (Cable, 2013) which displays an interactive map in which every person, based on their race and home address, are represented by a different colored dot. Together these different colored dots show the racial makeup of different geographic areas. The Racial Dot Map clearly shows how segregation works geographically. If society was integrated (as many still erroneously believe), it would be hard to distinguish racial dot patterns in cities, towns, etc. However, what you can see in almost every metropolitan area and small urban environment is racial segregation. This reality shocks teacher candidates as they tangibly see the ways that segregation works on a national scale. I then choose a specific city (e.g., St. Louis) and put the "Racial Dot Map" next to the "Opportunity Atlas" to show the interrelatedness between race, geography and household income.

After learning the ways that race, geography and income intersect, we then discuss how schools are funded. While many of the teacher candidates know that property taxes fund a majority of the school budget in Illinois, they do not have a strong grasp on why this is racist. However, when they see the racial segregation, the depressed incomes in communities of color (particularly Black and Brown), and school funding through property taxes, they begin to make the connections in seeing how race and racism is structural, both geographically and financially, and how it limits educational opportunities. Where children grow up dictates the kinds of opportunities and resources they will be afforded in public schools (Siegel-Hawley, 2013). To prove this unjust reality, we then turn to the state's school report cards that unveil the amount of funding available per pupil in schools across the state. We compare the per pupil expenditure of wealthy, white majority communities and compare them to communities where the majority are non-white. The racial inequity is startling. We then have discussions about how unequal schooling conditions are well-known and, thus, readily accepted as the status quo. To prove the claim that the miseducation of Black children is intentional and normalized, I introduce a case study from St. Louis where New York Times writer, Nikole Hannah-Jones, talks about the ways in which integration was fought by a predominantly segregated white community in the recent past. In a two-part episode of This American Life, entitled "The Problem We all Live With" (Hannah-Jones, 2015), Hannah-Jones walks us through the nuanced ways that white majority communities entrenched in economic and educational privilege continue to defend their resources, particularly from Black students and families. Throughout these activities, I challenge my teacher candidates about what it would take for Black and Brown students to have educational equality. I ask them to re-investigate their commitment to not discriminate based on race versus a commitment towards anti-racist praxis. As mentioned earlier, the commitment 
to not racially discriminate is meaningless if teachers cannot regularly identify racist practices within themselves and within schools. We further discuss that striving towards anti-racist praxis means re-examining power structures (e.g., teachers, administrators, board of education) and actively working towards abolishing practices that support and normalize Black educational oppression (e.g., language discrimination, suspension rates, teacher demographic).

\section{CRITICAL RACE CONSCIOUSNESS IN FIELDWORK EXPERIENCES}

Practicums, while both valuable and necessary, are not inherently neutral spaces. Schools exist within a racialized hierarchy whereby white students, teachers and communities benefit the most (Ladson-Billings \& Tate, 1995). Understanding the historic and continued racial oppression in school systems are necessary in order to make careful decisions when finding field placements. We, therefore, call for a renewed focus on selecting clinical sites with the explicit purpose of fostering teacher candidates' critical race consciousness. We begin by highlighting several critiques from our own experiences that problematize the selection of clinical sites, followed by a guiding set of questions that help programs critically interrogate their clinical selection process. We then apply these questions when considering white majority and racially diverse schools as potential clinical sites.

\section{Selection Criteria for Clinical Placements}

Colleges with white majority teacher education programs must thoughtfully consider how school sites are selected for field placements. In our experiences, selection criteria for placements focus on geographic distance from campus, school districts' willingness to host teacher candidates, and/or past relationships or partnerships with schools. While these methods may appeal to practical logistics, they obfuscate the role of race and systems of white supremacy that undergird the selection criteria. To select sites simply because they are close by, are willing, or because "we always have," places an extraordinarily low standard for selecting placements, especially when juxtaposed to the myriad high standards programs place for teacher candidates in all other areas (e.g., course content, attendance policy, certification, etc.). It is duplicitous and white-serving, then, to continue such a low threshold of entry for host schools, particularly for such a significant portion of teacher preparation. We pose the following questions for teacher education programs to critically interrogate the process and criteria by which clinical placements are selected.

- What is the process by which schools and districts are selected as host sites for teacher candidates?

- Who do current selection criteria serve? Who or what is sacrificed under the current selection process?

- What does this school site offer in terms of experience when it comes to fostering teacher candidates' critical race consciousness? 
- What does this school site offer white teacher candidates' in their understanding of how race functions within the classroom space?

- Is the school site a safe space for teacher candidates' of color to develop their skills without having to placate white dominant norms?

- Is the school district actively pursuing and committed to anti-racist praxis within multiple areas of school oversight: curriculum, teacher recruitment, hiring of administrators, school policies, teacher recruitment, etc.?

\section{Problematizing Clinical Placements}

An essential issue that must be problematized is the normalcy of majority white clinical placements in teacher preparation programs, particularly regarding what these sites offer in fostering teacher candidates' critical race consciousness. If the school is majority white both in teacher and student demographic, we must ask tough questions about whether these placements provide the necessary experience for teacher candidates to be prepared for teaching a racially diverse classroom in the future. Clinical placements hosted by white cooperating teachers with white teacher candidates often function as mentoring sites into white dominant ways of doing school. We are intimately aware of the rationalizations often provided to sustain such white systematic norms: teachers are a work in progress and still need additional development regarding racial equity; sites understand some equity-related issues (e.g., income, gender, etc.), which is better than nothing; there are excellent teachers in content (e.g., guided reading, math instruction) who still need growth in criticality; there are no perfect teachers, and waiting for such will yield zero clinical placements. In each of these rationalizations, issues of race and confronting white supremacy play a separate and ancillary role from content and other aspects of learning. Critical race theory, however, underscores the centrality and pervasiveness of race and racism. Thus, within the context of rationalizing majority white placements, we contend that critical understandings of race pervade content learning (e.g., how excellent can guided reading instruction be when it is only successful with white monolingual students?), and should be centered instead of counted as an aside (e.g., would a teacher be selected to mentor teacher candidates if they were not competent in math instruction, or was not successful in teaching children how to read?). We must grapple, therefore, with the continued use of majority white clinical sites that do not afford the opportunities needed to prepare teacher candidates for a rapidly changing student demographic.

Another essential question for teacher education programs to consider is whether or not their clinical sites are safe spaces for teacher candidates of color. As both supervisors and professors overseeing clinical sites, we have experienced firsthand the marginalization experienced by teacher candidates of color within white dominated classroom spaces. The onus is often placed on teacher candidates of color to assimilate rather than challenging teacher education departments to pre-empt these structural concerns within the clinical selection and 
assignment process. Moreover, any pre-emptive changes to place teacher candidates of color in diverse classrooms is often met with giving white schools the benefit of the doubt, and only addressing race-based issues when they inevitably arise. This approach does nothing to consider the racial trauma that can be experienced in white majority schools and gives the benefit of the doubt to white cooperating teachers and administrators at the mental and emotional expense of teacher candidates of color. We must care more about teacher candidates of color who are historically and currently underrepresented within the teaching profession and their experiences throughout their fieldwork placements.

Finally, as teacher preparation programs attempt to ameliorate the lack of diverse clinical placements through more racially diverse placements, we contend that the goal should not be to simply increase non-white school sites. As previously mentioned, diverse and "urban" sites can house teachers (across racial lines) who practice deficit ideologies and beliefs. Instead, teacher preparation programs should find racially diverse placements that are engaged in antiracist praxis, and cooperating teachers who are critically aware of how race and racism function within education. We acknowledge that this is difficult work which requires significant efforts to uproot established practices. However, when those established practices conform to white dominance in a society yearning for racial equality, we believe the effort is worthwhile.

\section{CONCLUSION}

Teacher education programs continue to incorporate diversity and equity-related topics throughout their courses and fieldwork. Yet, merely increasing the diversity quotient alone does little to unpack the racialized issues pertaining to a majority white teacher candidate demographic that comes from predominantly white spaces. While there already is a large amount of literature that discusses deconstructing and transforming teacher education programs, white hegemony continues. We, therefore, offer ideas and practical suggestions not as a definitive and prescriptive way forward, but as a commitment in dismantling white supremacy within the teaching profession. We do not offer a checklist, since no checklist will fully dismantle the structural permanency of white supremacy. Instead, we offer guidelines to help white majority teacher education departments to think through and confront practices that maintain white dominance. Furthermore, as Sleeter (2013) notes, there is no substitution for a racially diverse teaching force. No amount of curricular adjustments or approaches focused on racial awakening will dismantle an education system based on white supremacy and dominated by white teachers. Teacher education programs that want to offer more critical coursework without closely looking at the racial makeup of their teacher candidates continue to support a system that privileges white people.

There is much at stake when racial inequality is not centered in teacher education. As Howard (2019) writes, "some of the most important stakeholders who will serve as arbiters of how the new racial realities will be understood are classroom teachers" (p. vii.). Future teachers 
need to be prepared to understand the ubiquitous role that race plays within schooling and within their own classroom practices. This preparation requires teacher education programs to actively seek anti-racist praxis within their departments in terms of teacher recruitment, course development, and fieldwork placements.

\section{REFERENCES}

Alim, H. S., Rickford, J. R. \& Ball, A. F. (Eds.). (2016). Raciolinguistics: How language shapes our ideas about race. New York: Oxford University Press.

Baker-Bell, A. (2018). "I can switch my language, but I can't switch my skin": What teachers must understand about linguistic racism. In E. Moore Jr., A. Michael, \& M. W. PenickParks (Eds.), The guide for white women who teach black boys (pp. 97-107). Corwin.

Baker-Bell, A. (2020). Linguistic justice: Black Language, literacy, identity, and pedagogy. New York: Routledge.

Baker-Bell, A., Butler, T., \& Johnson, L. (2017). The pain and wounds: A call for critical race English education in the wake of racial violence. English Education, 49(2), 116-129.

Bartolomé, L. I. (2004). Critical pedagogy and teacher education: Radicalizing prospective teachers. Teacher Education Quarterly, 31(1), 97-122.

Bell, D. A. (1980). Brown and the interest-convergence dilemma. In D. Bell (Ed.), Shades of Brown: New perspective on school desegregation (pp. 90-106). Teachers College Press.

Bomer, R., Dworin, J., May, L., \& Semingson, P. (2008). Miseducating teachers about the poor: A critical analysis of Ruby Payne's claims about poverty. Teachers College Record, 110(12), 2497-31.

Cable, D. A. (2013, July). The racial dot map. University of Virginia. https://demographics.virginia.edu/DotMap/index.html

Carter, D. J. (2008). Cultivating a critical race consciousness for African American school success. Educational Foundations, 22(1), 11-28.

Case, K., \& Hemmings, A. (2005). Distancing strategies: White women preservice teachers and antiracist curriculum. Urban Education, 40(6), 606-626.

Chetty, R., Friedman, J. N., Hendren, N., Jones, M. R., \& Porter, S. R. (2018). The opportunity atlas. https://www.opportunityatlas.org/

Cornbleth, C. (2008). Diversity and the new teacher. New York: Teachers College Press.

Crenshaw, K. (1989). Demarginalizing the intersection of race and sex: A Black feminist critique of antidiscrimination doctrine, feminist theory and antiracist politics. In University of Chicago Legal Forum, 1989, 139-158.

Crowley, R. M., \& Smith, W. (2015). Whiteness and social studies teacher education: Tensions in the pedagogical task. Teaching Education, 26, 160-178. 
Evans-Winters, V., \& Hoff, P. T. (2011). The aesthetics of white racism in pre-service teacher education: A critical race theory perspective. Race and Ethnicity and Education, 14, 461479.

Flynn, J. E. (2015). White fatigue: Naming the challenge in moving from an individual to a systemic understanding of racism. Multicultural Perspectives, 17, 115-124.

Freire, P. (1973). Education for critical consciousness. New York: Seabury Press.

Grant, C. A., \& Agosto, V. (2008). Teacher capacity and social justice in teacher education. In M. Cochran-Smith, S. Feiman-Nemser, \& D. J. McIntyre (Eds.), Handbook of research on teacher education: Enduring questions in changing contexts, ( $3^{\text {rd }}$ ed., pp. 175-200). Routledge.

Hannah-Jones, N. (speaker). (2015, July 31) The problem we all live with [Audio podcast]. NPR. https://www.thisamericanlife.org/562/the-problem-we-all-live-with-part-one

Hollins, E. R. (2011). Teacher preparation for quality teaching. Journal of Teacher Education, 62(4), 395-407.

Howard, T. C. (2019). Foreword. In K. T. Han \& J. Laughter (Eds.), Critical race theory in teacher education: Informing classroom culture and practice, (pp. vii - ix). Teachers College Press.

Johnson, L. L. (2018). Where do we go from here? Toward a critical race English education. Research in the Teaching of English, 53(2), 102-124.

Kohli, R. (2014). Unpacking internalized racism: Teachers of color striving for racially just classrooms. Race, Ethnicity, and Education, 17(3), 367-387.

Ladson-Billings, G. (1998). Just what is critical race theory and what's it doing in a "nice" field like education? International Journal of Qualitative Studies in Education, 11, 7-24.

Ladson-Billings, G. (2011). Asking the right questions: A research agenda for studying diversity in teacher education. In A. F. Ball \& C. A. Tyson (Eds.), Studying diversity in teacher education (pp. 362-374). American Educational Research Association.

Ladson-Billings, G., \& Tate, W. F. (1995). Toward a critical race theory of education. Teachers College Record, 97(1), 47-68.

Lee, A. Y., \& Lee, A. J. (in press, 2020). Critical race methodologies. In N. K. Duke \& M. H. Mallette (Eds.), Literacy Research Methodologies ( $3^{\text {rd }}$ ed.). Guilford Press.

Lippi-Green, R. (2012). English with an Accent: Language, ideology, and discrimination in the United States. New York: Routledge.

Liu, K., \& Ball, A. F. (2019). Critical reflection and generativity: Toward a framework of transformative teacher education for diverse learners. Review of Research in Education, 43, 68-105.

Matias, C. E., Viesca, K. M., Garrison-Wade, D. F., Tandon, M., \& Galindo, R. (2014). What is critical whiteness doing in our nice field like critical race theory?" Applying CRT and CWS to understand the white imaginations of white teacher candidates. Equity and Excellence in Education, 47(3), 289-304. 
Milner, H. R. (2008). Critical race theory and interest convergence as analytic tools in teacher education policies and practices. Journal of Teacher Education, 59, 332-346.

Milner, H. R., \& Laughter, J. C. (2014). But good intentions are not enough: Preparing teachers to center race and poverty. The Urban Review, 47(2), 341-363.

Milner, H. R., Cunningham, H. B., Delale-O'Connor, L, \& Kestenberg, E. G. (2018). These kids are out of control: Why we must reimagine "classroom management" for equity. Thousand Oaks: Corwin.

Nieto, S., \& McDonough, K. (2011). "Placing equity front and center" revisited. In A. F. Ball \& C. A. Tyson (Eds.), Studying diversity in teacher education (pp. 341-361). American Educational Research Association.

Nieto, S., Bode, P., Kang, E., \& Raible, J. (2008). Identity, community, and diversity: Retheorizing multicultural curriculum for the postmodern era. In M. Connelly, M. Fang He, \& J. Phillion (Eds.), Handbook of curriculum and instruction (pp. 176-197). Sage Publishers.

Paris, D. (2011). Language across difference: Ethnicity, communication, and youth identities in changing urban schools. New York: Cambridge University Press.

Picower, B. (2009). The unexamined Whiteness of teaching: How White teachers maintain and enact dominant racial ideologies. Race Ethnicity and Education, 12(2), 197-215.

Sato, M., \& Lensmire, T. (2009). Poverty and Payne: Supporting teachers to work with children of poverty. Phi Delta Kappan, 90(5), 365-370.

Sensoy, O., \& DiAngelo, R. (2011). Is Everyone Really Equal?: An Introduction to Key Concepts in Social Justice Education. New York: Teachers College Press.

Siegel-Hawley, G. (2013). City lines, county lines, color lines: The relationship between school and housing segregation in four southern metro areas. Teachers College Record, 115(6), $1-45$.

Sleeter, C. E. (2017). Critical race theory and the Whiteness of teacher education. Urban Education, 52(2), 155-169.

Smitherman, G. (1977). Talkin' and Testifyin': The Language of Black America. Boston, MA: Houghton Mifflin.

Smitherman, G. (2017). Raciolinguistics, "mis-education," and language arts teaching in the 21st Century, Language Arts Journal of Michigan, 32(2), 4-12.

U.S. Department of Education. (2016). The state of racial diversity in the educator workforce. Washington, DC: U.S. Department of Education, Office of Planning, Evaluation and Policy Development, Policy and Program Studies Service.

Young, V. A. (2010). Should writers use they own English? lowa Journal of Cultural Studies, 12(1), 110-118.

Zeichner, K. (2006). Reflections of a university-based teacher educator on the future of college-and university-based teacher education. Journal of Teacher Education, 57(3), 326-340. 
Zeichner, K. M., \& Tabachnick, B. R. (1981). Are the effects of university teacher education "washed out" by school experience? Journal of Teacher Education, 32(3), 7-11.

\section{APPENDIX}

Critical Reflective Autobiography Questions (Milner et al., 2018, p. 63-64)

- What is your racial background? How do you know?

- In what ways does your racial background privilege you (or not) in society?

- How and when did you first see yourself as a racial being? How do you know?

- What is your socioeconomic background? How do you know?

- What is your socioeconomic background? How do you know?

- What was your socioeconomic background growing up?

- How has your socio-economic background influenced your educational opportunities?

- In what ways do your race and socioeconomic background shape your worldview, what you do, how you experience the world, and what/how you teach?

- How does my racial and socio-economic background influence decisions I make about what to emphasize in course content, how to teach it, and classroom management practices?

- How might students of gender identity, sexual orientation, racial and socioeconomic backgrounds different than my own respond to my instructional choices and classroom management strategies and approaches?

- How does my personal experience with regard to family structure and family life patterns growing up shape my expectations of student behavior in the class?

- How do my beliefs about personal and community responsibility inform the expectations I have about how students treat the physical space of our classroom and school?

- How do I shape instructional practices and classroom management strategies in ways that create classroom spaces of collective expertise, interest, and motivation? 